\title{
Franco-Prussian War 1870-1871: Voluntary Aid for the Wounded and Sick
}

\author{
VALENTINE A. J. SWAIN,* F.R.C.S.
}

Though the military, political, and strategic aspects of the Franco-Prussian War have been fully recorded little attention has been given to the medical side of this bitter struggle. ( $\mathrm{Sir}$ ) Edward Cook, Florence Nightingale's biographer, wrote that "the outbreak of the war had found English philanthropy unprepared," and Sir Rickman Godlee, in his biography of Lord Lister, added that "the sound of battle caused the usual rush of British and American volunteers who were welcomed by both sides in those days of comparatively ill developed army medical services."

Though the International Committee for the Relief of Wounded and Combatants had been established in 1863 at Geneva, there was no British Society for Aid of the Sick and Wounded in time of war; but, stimulated by the outbreak of war and initiated by (Sir) John Furley and Captain C. J. Burgess, a meeting was held in London on 4 August 1870-the day on which the Prussian Army advanced into Alsace. At this inaugural gathering, with the Queen as Patron, Colonel Loyd-Lindsay (Lord Wantage), V.C., M.P., was its chairman. Support for this project was given by Florence Nightingale, who "if not sick she would have gone out as a nurse." She also gave welcome advice on the nursing services, the administration of field ambulances, and equipment. From time to time during the war she received news from various agents abroad, in particular from Miss Lees (Mrs. Dacre Craven) of the Nightingale School, who was in charge of a highly efficient Prussian hospital under the auspices of the Crown Princess of Prussia, Victoria.

Initially the Committee of the British National Society sent out 10 English surgeons and five nurses (to Germany) and owing to a "great demand for surgeons" the number rose by the end of September to 62 , with 16 ladies who acted as nurses. They served gratuitously, in equal proportions the French and German armies. Each surgeon was given £1 a day by the Committee to pay expenses of medical comforts of patients in military hospitals. Large sums of money had been collected and stores and equipment had been provided where needed, including surgical instruments, chloroform, Liebig's meat extract, water-beds, and air cushions, and later "to arrest the additional horror of pestilence in the hospitals "Condy's Fluid' had been liberally placed at their disposal."

So rapid was the course of events that the doctors on the Prussian side "followed the tracks of. war," whereas those working with French forces "found the war coming towards them." Eye-witness accounts from volunteers and observers serving with the two belligerent nations reflect this changing scene.

\section{“Bart's Men"}

At the onset of the war a volunteer medical contingent of the British Red Cross, consisting of "Bart's men," Mr. Henry Rundle, F.R.C.S., Mr. William Athill, dresser, Mr. J. C. Galton, with Dr. Charles Mayo, who had already served in the
American Civil War, in charge, arrived in Potsdam. They were received by the Crown Princess of Prussia at the royal palace; there, at the medical stores, they saw ladies of all ranks hard at work making charpies, $\nmid$ bandages, and cushions, etc. General interest was evoked by the large numbers of hypodermic syringes brought by the English team. After touring the capital city and the Unter den Linden with its cafés thronged with sons of the Fatherland, enthusiastic and assured of victory, the party, armed with their official passports, proceeded towards Metz. This French fortress town was being blockaded by Prince Frederick-Charles's army after the early Prussian successes at Colombey-Nouilly, Vionville, and Gravelotte. Around this town the churches were used as hospitals for the reception of the wounded and the ground was dotted with graves- "Here rest friend and foes together."

"Following the tracks of war" they distributed medical stores en route and reached Gorzé $(8$ miles $(13 \mathrm{~km}$.) southwest of Metz), where "a huge convent was packed full, and doctors, medical volunteers and Sisters of Mercy were

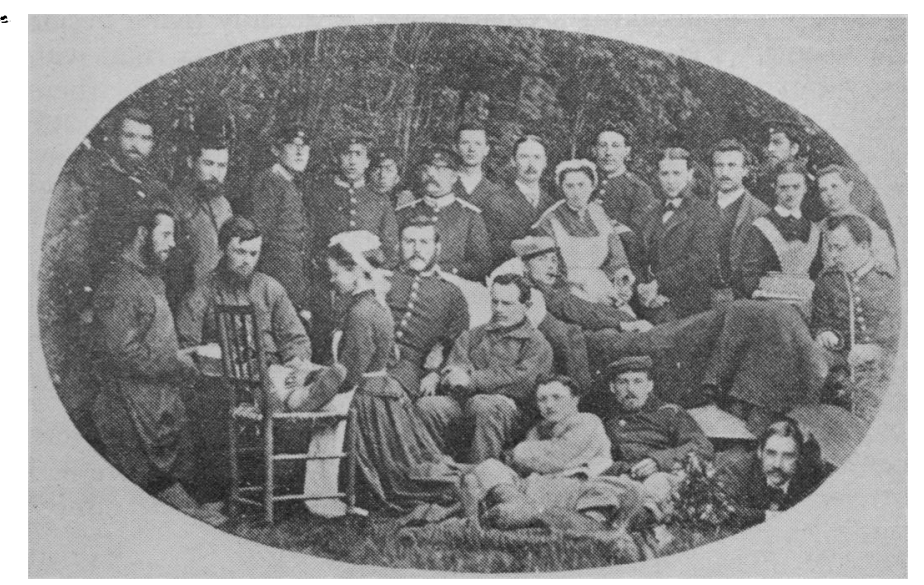

FiG. 1.-Doctors and patients at Alice War Hospital, Darmstadt, 1870-1. (From With the Red Cross in the Franco-German War 1870-71. Rundle, Henry (1911) London, Werner Laurie). Reproduced by permission of the publishers.)

tending wounded everywhere." After providing supplies at Rezonville ( 5 miles $(8 \mathrm{~km}$.) north of Gorzé) they established a 150- to 250-bedded hospital at Darmstadt, which was under the auspices of Prince Louis of Hesse-Darmstadt. Here for the next nine months 926 sick and wounded were treated. Later Mr. H. W. Page, Dr. Robert Cory, Dr. Buck, and Mr. H. E. Jackson joined the staff of the Alice Hospital at Darmstadt, which afterwards became the "State Reserve Hospital" (Fig. 1).

\section{Organization of Medical Service}

On 27 September, soon after the fall of Strasbourg, "with the long expected white flag flying on one of the pinnacles of 
the cathedral," some of the British Red Cross workers entered the city, "where blood and iron, passion and hatred have done their worst": the Bibliotheque had been "reduced to a charred ruin," with the loss of its precious books and manuscripts. In the city they found horseflesh and enough bread for all, but salt and milk were lacking. Chloroform was sent into the city by the Red Cross Society, and this was "probably the first instance of such mitigation of the horrors of a siege." Near by they met Sutherland Edwards, The Times correspondent, and Ernest Hart, editor of the British Medical fournal.

About that time Dr. J. W. Thudicum (of St. Thomas's Hospital) of the German Aid Society of London reported that (Sir) J. Simon, F.R.S., Medical Officer of the Privy Council, with 12 surgeons had established a 200-bed hospital at Bingen-on-Rhine. This was destroyed by a violent storm on 30 October, "exposing the wounded to the element."

Archibald Forbes, the English correspondent, who also followed the Prussian Army, in his scanty reference to the medical service, considered that the Germans were well organized in controlling sickness and attending to the wounded. The Queen of Prussia took a personal interest in their care. Furthermore, Forbes wrote: "Each soldier in the Prussian Army carries in his knap-sack some lint and a bandage, so that when he falls the surgeon can instantly run up and open the knap-sack and apply a bandage; a certain number of the N.C.O.s carried tourniquets, though in the heat of battle cannot be applied but available later. Each soldier has a card with his name around the neck. The surgeon writes on the card the severity of the wound and .whether to be moved" for the guidance of the ambulance personnel.

Following the early severe fighting Forbes recorded: "After the battle now carriage after carriage is coming in here from Wörth, in which lying on the straw, are combatants of the day before yesterday-Germans often peaceably living beside Frenchmen. Every hour and a half or two hours a train with fifty carriages leaves here for the towns in Germany, where military hospitals are established. In the meantime, those who are seriously wounded are taken into the station and temporary barrack hospital. If but slightly hurt, they are placed upon straw in the open air about the railway station. When I arrived a train had just left but $a$ hundred wounded remained. Sisters of Mercy went from one to the other laying ice upon the wounds and handing round bread and refreshments, and a piece of dry black bread seemed to be more thankfully received than the greatest delicacy. It was touching to see how friend and enemy tried to assist each other into the carriages. The same men who fought $\mathbf{4 8}$ hours before had striven to destroy one another were now using their utmost endeavours to alleviate each other's pains."

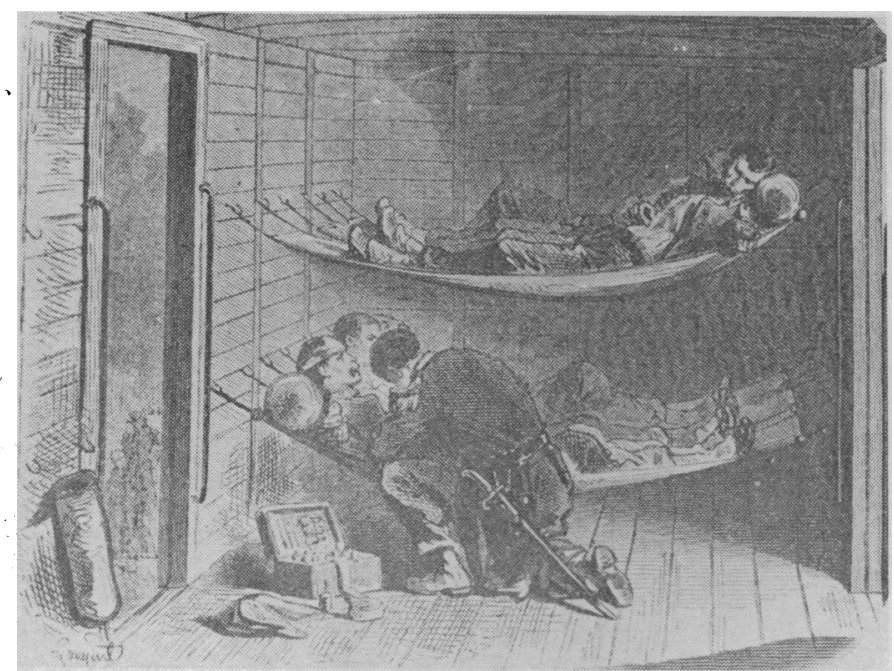

FIG. 2.-Wagon-ambulance for transport of wounded. From Vaultier, $R$. (1957). Presse Médicale, 65, 2203. Reproduced by permission of the publishers.
At Spicheren Forbes observed the excellent work of the hospital corps in tending and transporting wounded. At night the Sisters of Mercy could be seen "swathed in black bending over a prostrate form or flitting ghost-like in the van of an ambulance party." (Fig. 2) The Hospitals at Saarbrücken were on the whole very good but were ill-prepared for the unexpected call on their services; houses were willingly thrown open for the wounded whether they wore "a. spiked helmet or a pair of red breeches." Most of the dead had been buried, for "the whole of the ground was thickly dotted over with graves where friend and foe slept at peace with each other in one grave." Within 24 hours about 2,000 wounded Prussian and French were transported to "large towns all along the Rhine."

\section{Experience in Paris}

The reception of the English contingent of the National Aid Society in Paris contrasted with that received by those in Potsdam, for the supposed preparedness of the French to the "last gaiter button" was hardly true. (Sir) William MacCormac, F.R.C.S., recalled his experience of arriving in Paris soon after the declaration of war, anxious to "see what military surgery was like." He was reassured by Nélaton, organizer of the French Aid Society and one of Napoleon's medical advisers, that he would be welcomed in Metz. Here he accompanied M. Hermann, Medecine en Chef de l'Hôpital Militaire de Metz, and MacCormac saw some of the early wounded-"it was extraordinary to see how balls . would traverse limbs from one side to the other and yet not injure either the bones, important vessels or the nerves." The chassepot bullet had a small entry wound and "with its gyration scooped at its exit a trumpet like mouth."

The French treatment consisted of applying a mass of charpies by bandage to the wounds. MacCormac, a disciple of Lister's method, noted that l'acide phenique was freely used, but this was not the general practice in most French hospitals, in fact it was not encouraged. Unexpectedly, he was obliged, owing to the imminent siege of Metz, to return to Paris lest he be arrested as a spy, for war hysteria and spy fever led to the imprisonment of many "alien" volunteers and observers. On his return journey by train he learnt of bitter fighting at Wörth and Wissembourg and how the "mitrailleuse faisait tomber les hommes comme des mouches." In Paris he joined a party of eight American and eight English surgeons-namely, Dr. Marion Sims, who had served in the American Civil War, Dr. Pratt, Dr. May, Dr. Tilghman, Dr. Nicoll, Mr. Hayden, Mr. Wallis, and Mr. Harry Sims (Americans); and Dr. Frank, Dr. Webb, Dr. Blewitt, Dr. Wyman, Mr. Hewitt, Mr. Scott, and Mr. Ryan (English).

Anxious to get to the seat of war without delay they set forth on 28 August from the Champs-Elysées with their equipment, saddlehorses, and male nurses and stores. They hoped to reach MacMahon's headquarters, then at Sedan, so as to set at once to work on the nearest battleground. By chance they saw Emperor Napoleon at Sedan railway station, with his entourage of marshals and generals; no doubt Dr. Conneau, armed with lithotomy instruments, was in the party, for at that time Napoleon was an ill man, requiring catheterization twice a day. On reaching the city the AngloAmerican party was allocated the Caserne d'Asfeld by Dr. Duplessy, Chief of the Military Hospitals of Sedan. This barracks had been converted into a 384-bedded hospital and stood on the ramparts of Sedan, overlooking the Meuse.

\section{Scene Around Sedan}

Soon after their arrival on the eve of the attack, the hospital became overwhelmed with work, for in the Battle of Sedan the wounded, exclusive of the dead, amounted to 12,500 . 
Forbes, who had arrived with the Prussians, vividly reported the scene: "We saw where MacMahon lay wounded and also how full the town was of troops. They were swarming, densely packed, everywhere. Of the wounded, some were in churches, the houses, public buildings and others lying unheeded and jostled in the courtyards: the dead were everywhere-in the gutters trampled on by the living, in the swampy margins of the moat, littering the narrow way through the glacis and the fortifications, lying some of them on the steps of the church, the sight was one never to be forgotten."

Such was the scene around. Inside the hospital Dr. Marion Sims, surgeon in charge, reported that on 31 August 36 wounded were treated, but within the next 48 hours every bed was occupied, and in that week the team was short-handed and exhausted with sorting out, treating the light and seriously wounded, and operating. In addition on 31 August a relief team, consisting of Dr. Sims and five others, set forth with their ambulance cart loaded with dressings, instruments, chloroform, and medical comforts to the near-by village of Balan, where 200 wounded lay. unattended; there an empty house was set up as a hospital and within 24 hours all were treated, procedures including amputations and removal of shell fragments-some by candlelight. After this task MacCormac returned to Sedan, leaving Blewitt and Frank at Balan. Another field hospital was set up at Bazeilles, to become a smouldering ruin a few days later.

The next morning after the dense fog had lifted, the Caserne became enveloped in the fighting, with the fire of heavy guns, the mitrailleuse, and rifle bullets. Several times the hospital was hit. Cases continued to arrive; dressings and operations continued all day. The next day, a day of bright sunshine, though all was quiet the wounded still came. "The longest day must come to an end and so did the 2nd September," wrote MacCormac. By his recent experience he stressed the need for an early and complete examination of gunshot wounds before inflammation set in, the cautious use of bullet-extraction forceps, early primary amputation, and the use of chloroform and carbolic lotion.

With Marshal MacMahon wounded and the French Army in danger of annihilation, Sedan capitulated. The Emperor was made prisoner of war. The Germans had about 9,000 casualties and the French 17,000 . The decisive victory of Sedan saw the entry of Prussian troops into the city to the "strains of splendid music" in heavy rain. On 11 September the ubiquitous Captain Brackenbury, R.A., who had at the onset of the war set up a stores depot in Arlon in Luxemburg, paid a welcome visit to the Caserne, and as superintendent of the establishment and lines of communication to field hospitals provided food, bedding, and news of outside events. Soon further stores arrived, and assistance in the persons of Dr. Markheim, Mr. Marcus Beck, Dr. Duncan, and Mr. R. W. Parker. Lady nurses-Miss Pearson, Mrs. Mason, Miss Barclay, and Miss Neligan-joined the hospital and confirmed MacCormac's view "that women are better adapted, both physically and morally for the charge of the sick than men, though not possibly on the battlefield, and should be procurable immediately afterwards." The visiting commissioner of the National Aid Society, Mr. H. Melville Merridew, bore witness that "whenever there are female nurses the hospitals are cleaner and more comfortable and the patients better looked after." He stressed that they should be properly trained and be under the surgeon's orders entirely to ensure smooth working. Seven nursing sisters arrived later to the seat of war in the charge of the Superior of All Saints Hospital, Margaret St.

In late September Dr. Marion Sims returned to New York and MacCormac left for England some weeks later. Both surgeons criticized the cumbrous French voluntary ambulance corps, with their large staff and heavy equipment causing some to arrive too late to be of any use. Ideally, MacCormac thought that four or five surgeons and assistant surgeons with smaller stores carried on horses or mules preferable. He had visited Stromeyer "the father of Military Surgery," who was in charge of several field ambulance units staffed by great civil surgeons (in the German armies). Regular medical staff conferences and hospital visits were encouraged in the army, which included about 4,000 doctors. The French had about 1,000 .

\section{Change of Events}

The Battle of Sedan marked the first phase of the war, and the British Aid Society faced this change of events. The "work of war" moved rapidly towards Paris after the proclamation of the Third Republic, but resistance to the Germans continued till the fall of Paris. So far the English Ambulance received its orders from the French and German national societies in Paris or Berlin, while funds, personnel, and equipment were provided mostly from London headquarters, largely from public subscriptions. Captain Furley, and Captain Burgess, and others saw that areas in need, both French and German, were supplied. The hospital established at Épernay with Dr. Frank, and other hospitals around, were provided for by depots based at Meaux and Versailles. Distribution was eased by the arrival at Havre of Woolwich ambulances and wagons, drawn by a hundred horses bought at the port. The hired French drivers-" "the street loafers from Havre"-were often suspected as spies. The Geneva Convention was mostly respected, and "supplementing the assistance and supplies furnished by the Army Medical Corps and Intendance of the respective belligerents" was allowed. The needs of the sick and wounded of both belligerents were met in accordance with the motto: Hostes dum vulnerati fratres.

Early in October Colonel Loyd-Lindsay, chairman of the English National Society, returned to France and arrived with Furley in his laden barouche at Versailles, where also the Prussian headquarters was established. Here he joined members of the disbanded Anglo-American ambulances and some of the Dutch and French Society busy in their philanthropic work at the beautiful Château de Moulin Rouge, with its Union Jack and Star-Spangled Banner flying. Part of his mission was to enter Paris with $£ 20,000$ for the French Society from the National Aid Society (Fig. 3).

From time to time relief parties left Versailles, one for Château d'Ecouen (north-west of Paris), where Dr. Tegner and his staff were treating sickness due to typhus, typhoid, and other infections. The cold-water treatment was adopted with success, the patients being snugly packed in wet sheets. Another party set out to join Dr. Pratt at the hospital in the

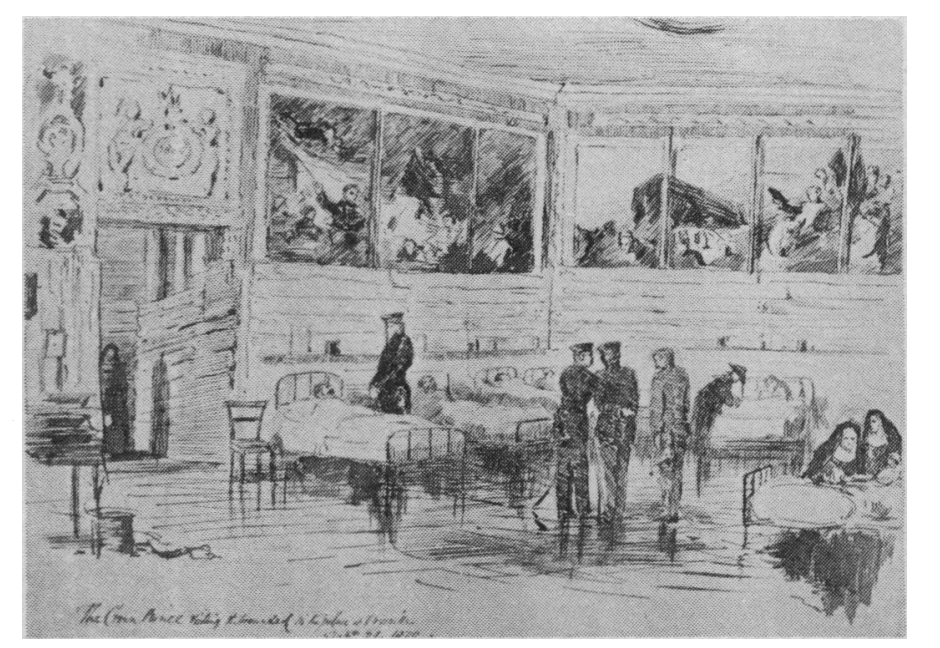

F1G. 3.- Crown Prince visiting wounded in Palace at Versailles 21 September 1870 . 
Church of St. Evurte, where Baron Van Langenbeck (Staff Surgeon General of the Prussian Army) was working. Often these journeys were hazardous, with danger of gunfire and of being arrested as spies or imbedded in mud. On a visit to Beaumont and Le Mans, the scenes of much fighting, Colonel N. W. Elphinstone representative of the British Red Cross at Tours, was told by Dr. Loeffler (Chief of German Medical Staff) that "the Germans were well provided for and he spoke in high terms of the kindness shown to the sick and wounded by the inhabitants of the town, but he admitted that the French wounded men were in great need of help."

The Nursing Sisters of Religious Orders played a major part during the war. Of one English sister Furley wrote: "She and her religious habit were more than once my best passport." Another, Marion Simon, Lady Superintendent of the Saxon ambulances, succoured the wounded passing through Lagny Station on the way back to Germany, where as many as 1,000 daily with infected and undressed wounds were returning eastwards to the bitter cold. All the available buildings near the station served as hospitals. Forbes happened to see the Prince of Saxe-Weimar visiting his troops there; he gave one wounded lad "a gold coin" and less tangible encouragement to others. "His visit did more good than my physic."

At Meaux provisions were thrown into the carriages of the wounded returning to Prussia. The railway which once transported the troops to battlefield returned full of Germans and some Frenchmen, wounded or sick, to the Fatherland. The American-style ambulance trains could accommodate two tiers of beds, laboratory, drugs shop, and cooking and living quarters for the staff. The horse-drawn Würtemburg field ambulances were also used; they could accommodate four stretchers and six walking wounded.

\section{Aftermath of War}

With the fall of Metz on 27 October, of the 20,000 soldiers who capitulated 9,000 were wounded, and 19,000 inhabitants were sick. Smallpox and typhus were beginning to appear. "Pyaemia, hospital gangrene and typhus had their sway on frames previously" debilitated by hardship and famine. Of the hospital stores the greatest lack was in the matter of leeches; Forbes stated that "a Dr. Ward paid 180 francs for two-for brain fever," also that "horseflesh and want of salt had killed off children like flies."-with the English ambulance among the first to commence a distribution of comforts and the National Society helped the fund with $£ 1,000$.

During the whole war it is estimated that among the German troops only 483 cases of smallpox appeared, as most of the soldiers had been vaccinated, whereas 4,178 cases of variola accounted for 2,000 deaths in the French forces, who were partly vaccinated.

Towards the end of 1870-l'année terrible-starving Paris became encircled more closely and was bombarded. So cold was the winter that the Seine was frozen over in places. From inside the French capital protests were made to Von Moltke for damaging the hospitals; his grim jesting reply that he soon hoped to get his batteries near enough to pick out the Red Cross flags more clearly did much to sway public opinion to support the French. "During the siege, the International Ambulances (as distinct from the British National Society) dragged the wounded and shattered out of the ruined houses and collected the corpses from the streets and buried them with some semblance of decency." (Fig. 4). After 132 days of siege Paris surrendered on 28 January 1871 . Inside the capital a Dr. Innes in his omnibus distributed his inexhaustible supply as from a wizard's hat, including rabbits, turkeys, bread, ham, and the inevitable Liebig's food.

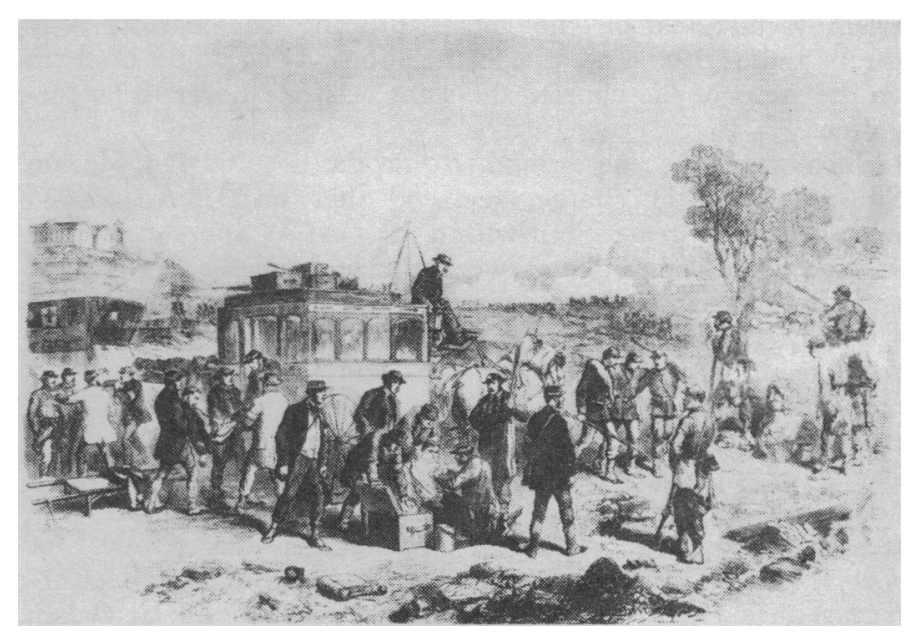

FIG. 4.-Defence of Paris: Ambulance Internationale Tending the Wounded on the Battlefield. By permission from the Illustrated London News November 5,1870 .

It was not until 7 February that Drs. Gordon and Wyatt were allowed to distribute stores in the city, where 30,000 sick and wounded lay.

\section{Conclusion}

The above account illuminates some of the known acts of humanity, but many deeds of valour and philanthropy remain for ever obscure. Rickman Godlee, reflecting on the FrancoPrussian War, concluded: "the malign influences of those scientific men whose genius is devoted to devising engines of death has so far more than counterbalanced that of their colleagues whose efforts are devoted towards the saving of life. The problem has therefore become more difficult and still awaits solution. Will it be solved by means of some new and undreamt of discovery? or will increasing horrors lead to the abolition of war and make the solution unnecessary?"

BIBLIOGRAPHY

Aronson, T. (1970). The Fall of the Third Napoleon, London, Cassell. Castiglioni, A. (1947). A History of Medicine, 2nd edn. London, Routledge

Ellis, H. (1969). A History of Bladder Stone. Oxford, Blackwell Scientific. Falls, C. (1969). Great Military Battles. London, Spring Books.

Forbes, A. (1871). My Experiences of the War between France and Germany. London, Hurst Blackett.

Fraser, Sir I. (1968a). Ulster Medical fournal, 37, Winter, p.l.

Fraser, Sir I. (1968b). St. Thomas's Hospital Gazette, 66, September, p.16. Furley, Sir J. (1905). In Peace and War. London, Smith, Elder.

Godlee, Sir R. J. (1917). Lord Lister. London, MacMillan.

Godlee, Sir R. J. (1917). Lord Lister. London, MacMillan. Howard, M. (1967). The Franco-Prussian War. London, Collins.

Rundle, H. (1911). With the Red Cross in the Franco-German War 1870-71 London, Werner Laurie.

Simpson, W. (1903). Autobiography of William Simpson, R.I. (Crimean Simpson). London, T. Fisher Unwin.

Vaultier, R. (1957). Presse Médicale, 65, 2203. 